\title{
To Formulate the Suitable Selection Criteria Based on Cluster and Association Analysis for Yield Maximization
}

\author{
Yogesh Kumar Nag* and R.N. Sharma \\ Department of Genetics and Plant Breeding, Indira Gandhi Krishi Viswavidyalaya, \\ Raipur C.G., India \\ *Corresponding author
}

\section{A B S T R A C T}

Keywords

Pigeonpea, Pigeonpea germplasm, Association analysis, Cluster analysis, Heterotic segregants

Article Info

Accepted: 12 December 2018 Available Online: 10 January 2019
Cluster and association analysis were studied for yield maximization and yield attributing traits in pigeonpea [Cajanus cajan (L.) Millsp]. There was significant variation observed for all the characters under study. Association studies revealed that seed yield per plant was positively associated with number of pods per plant, number of pod clusters per plant, number of primary branches per plant and pod length. Cluster analysis result showed existence of considerable diversity in pigeonpea germplasm accessions. The maximum inter cluster distance was observed in between cluster I and VI. Hence, genotypes belonging to cluster IV may be utilized as parent in future breeding programmes with the genotypes belonging to cluster I to obtain better/heterotic segregants.

\section{Introduction}

Pigeonpea [Cajanus cajan (L.) Millsp.] is the second most important pulse crop of our country. It is also known as red gram, arhar and tur. It is a rich source of protein and is grown in a wide range of environment. Pigeonpea seeds have $19-25 \%$ protein and are consumed as green peas, whole grain or split peas. It is hardy, widely adapted and drought tolerant crop. It is an important legume of the tropics and subtropics because of multiferous uses viz., source of food, fodder and fuel wood; material for fencing, for soil improvement through $\mathrm{N}$ fixation and wind barriers.

It is the fourth most important pulse crop in the world where in, India alone accounts for 85 per cent of the world supply (Fattepurkar et $a l ., 2004)$. It can grow under low fertility and harsh conditions due to its ability to use atmospheric nitrogen through biological nitrogen fixation up to $40 \mathrm{~kg} \mathrm{~N} \mathrm{ha}{ }^{-1}$ (Nene, 
1987), which is useful in maintaining soil health through increasing nitrogen availability and microbial activities.

\section{Materials and Methods}

\section{Experimental detail}

The experimental material was comprised of 45 pigeonpea germplasm accessions. The experiment was laid out in Randomized Complete Block Design (RBD) in two replications during kharif-2010-11. Experimental site has heavy (vertisol) soil. A fertilizer dose of 20N: 50P: $20 \mathrm{~K} \mathrm{~kg} /$ ha was applied. Each entry was sown in two rows of four meter length keeping $60 \mathrm{~cm}$ between rows and $15 \mathrm{~cm}$ between plants spacings. All the recommended package of practices was adopted to raise a good crop.

Observations on metric traits were recorded on single plant basis from five randomly selected competitive plants from each genotype separately. Observations were recorded characters namely Days to flower initiation was noted in terms of days from the date of sowing to the opening of first flower, Days to $50 \%$ flowering was noted in days from the date of sowing to the opening of first flower on approximately $50 \%$ plants in each plot, Days to maturity was noted in terms of days from the date of sowing to the stage when over $90 \%$ pods have matured, Plant height (cm) was measured in $\mathrm{cm}$ from ground level to the tip of main axis of physiologically matured plants, Number of primary branches per plant counted at physiological maturity, Number of pods per plant were counted from each selected plant at physiological maturity, No of pods per cluster were counted from each selected plant at physiological maturity, No of pod clusters per plant were counted from each selected plant at physiological maturity, Number of seeds per pod were counted at physiological maturity, 100 seed weight $(\mathrm{g})$ at
10 per cent (air dry) moisture content was recorded and Seed yield per plant $(\mathrm{g})$. The selected plants were harvested, threshed and winnowed separately. Finally the seeds were weighed in grams after drying them to appropriate moisture level.

\section{Statistical analysis}

\section{Analysis of variance}

The data obtained from the individual plant observations from randomized block design experiment were analyzed statistically as per the procedure given by Cochran and Cox (1957).

\section{Results and Discussion}

The estimates of phenotypic and genotypic coefficient are presented in Table 1. Association studies revealed that seed yield per plant showed the highest significant positive correlation with number of pods per plant $(\mathrm{r}=0.575)$ followed by number of pod clusters per plant $(\mathrm{r}=0.501)$, number of primary branches per plant $(\mathrm{r}=333)$ and pod length $(r=0.299)$. Moreover, number of pods per plant was found to be correlated positively with days to maturity $(\mathrm{r}=0.389)$, number of primary branches $(r=0.319)$ and number of pod clusters per plant ( $\mathrm{r}=0.717)$. Days to flower initiation had positive correlation with days to $50 \%$ flowering $(\mathrm{r}=0.747)$ and days to maturity $(\mathrm{r}=0.459)$. Whereas, days to $50 \%$ flowering showed positive correlation with days to maturity $(r=0.659)$. Hence, direct selection for number of pods per plant, number of pod clusters per plant and pod length may be advantageous for selecting the high yielding genotypes in pigeonpea from the available germplasm accessions. The experimental findings on correlation coefficient analysis are in general agreement with the results reported earlier by Mahamad et al., (2006), Mittal et al., (2006), Kalaimagal 
et al., (2008), singh et al., (2008), Sodavadiya et al., (2009), Linge et al., (2010) and Chandirakala and Subbaraman (2010).

In plant breeding, genetic diversity plays an important role because hybrids between lines of diverse origin, generally, display a greater heterosis than those between closely related parents. Genetic diversity arises due to geographical separation or due to genetic barriers to cross ability.

The choice of genetically diverse parents for hybridization is an important feature of any crop improvement programme for getting desirable segregants. The multivariate analysis based on Mahalanobis $\mathrm{D}^{2}$ or non-hierarchical Euclidean cluster analysis is used for divergence analysis. Multivariate analysis by means of Mahalanobis $D^{2}$ statistic is a powerful tool in quantifying the degree of divergence between biological population at genotypic level to assess the relative contribution of different components to the total divergence. The $\mathrm{D}^{2}$ analysis classifies the genotypes into relatively homogeneous groups in such a way that within cluster diversity is minimized and between clusters diversity is maximized. The respective genotypes from diverse clusters can be utilized in breeding programme depending upon the breeding objectives.

A set of 45 genotypes of pigeonpea were subjected to $\mathrm{D}^{2}$ analysis for twelve characters. Based on $\mathrm{D}^{2}$ values four clusters were formed (Table 2). This indicated that substantial diversity exists in the available gene pool of pigeonpea. Results of cluster analysis revealed that the cluster II was the largest which consisted of (16 accessions) followed by cluster III (12 accessions), I (9 accessions) and IV (8 accessions). From the clustering pattern, it was found that the pigeonpea germplasm accessions received from ICRISAT of Bastar origin were genetically diverse to each other.
Hence, the genotypes studied are reliable enough for hybridization and selection.

The maximum inter cluster distance was observed in between cluster I and VI (4.904) followed by between cluster II and IV (4.048) and cluster III and IV (3.599). This suggested that the hybridization programme involving parents from these clusters is expected to give higher frequency of better segregates or desirable combination for development of useful genetic stocks or varieties. The minimum inter cluster distance was observed in between II and III (2.125) followed by cluster I and II (2.518) and cluster I and III (3.178) indicating minimal diversity (differences) for the genes under study.

The maximum intra cluster distances was observed in cluster IV (3.674) followed by cluster I (2.818), cluster III (2.634) and cluster II (2.364)

The mean values for different characters were compared across the cluster and are presented in Table 3. Results of the analysis revealed that cluster I was found to be better for earliest days to flower initiation (100.50 days), earliest days to $50 \%$ flowering (122.72 days), earliest days to maturity (169.33 days) and number of seeds per pod (4.83) whereas, cluster III exhibited the highest 100 seed weight (10.17 g).

Similarly, cluster IV has better genotypes for more number of primary branches (16.38), number of pods per plant (375.75), number pods per cluster (3.12), number of pod clusters per plant (102.56), pod length $(5.58 \mathrm{~cm})$ and high seed yield per plant $(45.06 \mathrm{~g})$. The pattern of distribution of pigeonpea genotypes in various clusters revealed existence of considerable diversity present in the material (Table 4). The highest intra cluster distance was observed for the cluster IV. 
Table.1 Phenotypic (P), Genotypic (G) and Environmental (E) correlation coefficients among different yield traits in total gene pool of Pigeonpea

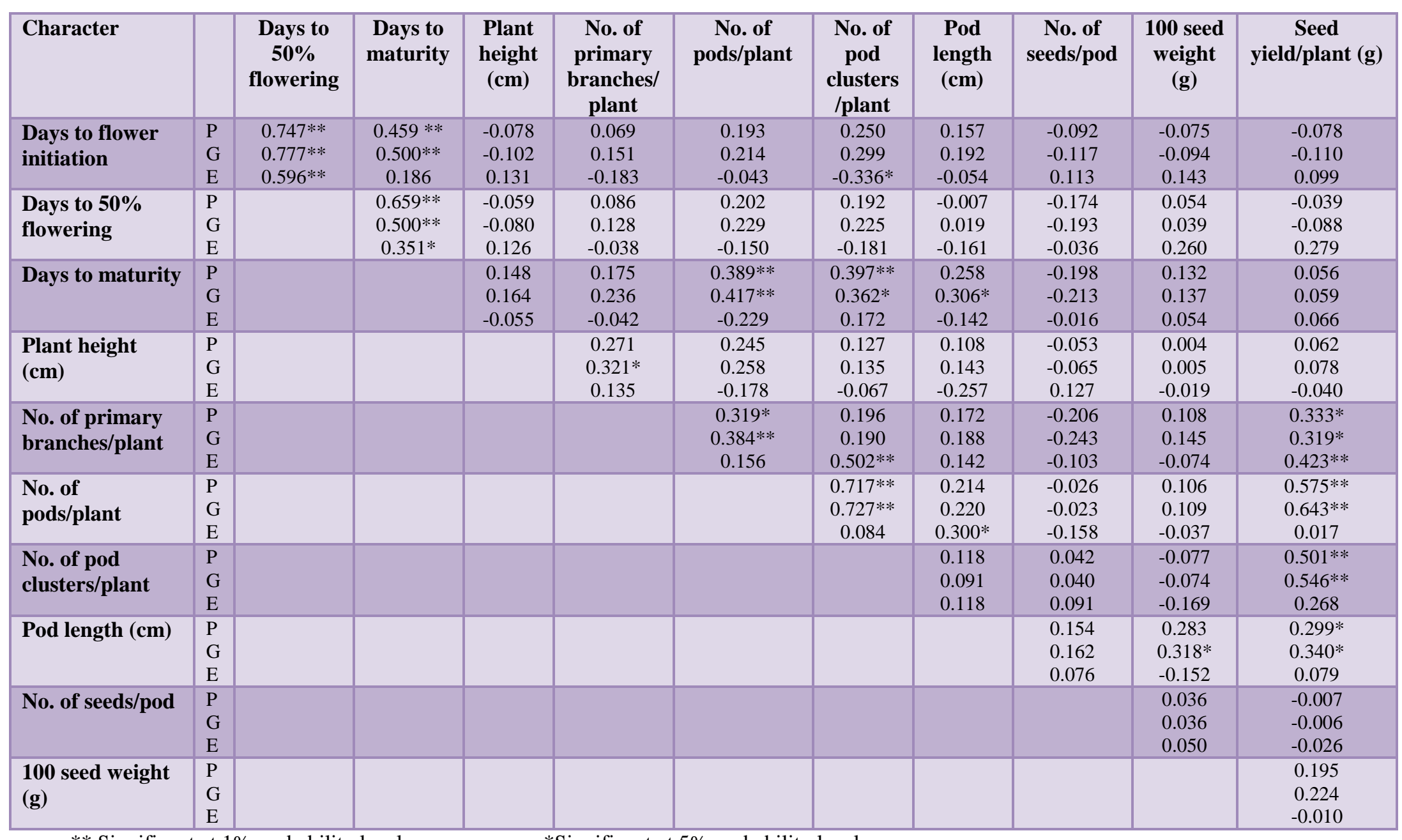

** Significant at $1 \%$ probability level

*Significant at $5 \%$ probability level 
Table.2 Genotypes of pigeonpea included in different clusters

\begin{tabular}{|c|c|c|}
\hline Cluster number & Number of genotypes included & Names of genotypes \\
\hline $\mathbf{I}$ & 9 & $\begin{array}{l}\text { UPAS-120, ICPL-6994, ICPL-6996, ICPL-6999, } \\
\text { ICPL-7000, ICPL-7359, ICPL-7364, ICPL-7409, } \\
\text { ICPL-7429 }\end{array}$ \\
\hline II & 16 & $\begin{array}{l}\text { ICPL-6992, ICPL-7001, ICPL-7003, ICPL-7004, } \\
\text { ICPL-7005, ICPL-7358, ICPL-7362, ICPL-7363, } \\
\text { ICPL-7366, ICPL-7367, ICPL-7374, ICPL-7389, } \\
\text { ICPL-7391, ICPL-7397, ICPL-7404, ICPL-7420 }\end{array}$ \\
\hline III & 12 & $\begin{array}{l}\text { ICPL-87119, BDN-2, ICPL-6992, ICPL-6997, } \\
\text { ICPL-7002, ICPL-7349, ICPL-7376, ICPL-7379, } \\
\text { ICPL-7382, ICPL-7392, ICPL-7393, ICPL-7406 }\end{array}$ \\
\hline IV & 8 & $\begin{array}{c}\text { ICPL-7373, ICPL-7384, ICPL-7385, ICPL-7388, } \\
\text { ICPL-7398, ICPL-7405, ICPL-7430 }\end{array}$ \\
\hline
\end{tabular}

Table.3 Inter and Intra cluster distance of genotypes in Pigeonpea

\begin{tabular}{|c|c|c|c|c|}
\hline Cluster & I & II & III & IV \\
\hline I & $\mathbf{2 . 8 1 8}$ & 2.518 & 3.178 & $\mathbf{4 . 9 0 4}$ \\
\hline II & & $\mathbf{2 . 3 6 4}$ & 2.125 & $\mathbf{4 . 0 4 8}$ \\
\hline III & & & $\mathbf{2 . 6 2 4}$ & $\mathbf{3 . 5 9 9}$ \\
\hline IV & & & & $\mathbf{3 . 6 7 4}$ \\
\hline
\end{tabular}


Table.4 Mean performance of genotypes in individual cluster for different yield traits

\begin{tabular}{|c|c|c|c|c|c|c|c|c|c|c|c|c|c|}
\hline \multirow[t]{2}{*}{ Clusters } & \multicolumn{13}{|c|}{ Characters } \\
\hline & Entries & $\begin{array}{l}\text { Days to } \\
\text { flower } \\
\text { initiation }\end{array}$ & $\begin{array}{l}\text { Days to } \\
50 \% \\
\text { flowering }\end{array}$ & $\begin{array}{l}\text { Days to } \\
\text { maturity }\end{array}$ & $\begin{array}{l}\text { Plant } \\
\text { height } \\
(\mathrm{cm})\end{array}$ & $\begin{array}{l}\text { Number } \\
\quad \text { of } \\
\text { branches } \\
\text { /plant }\end{array}$ & $\begin{array}{l}\text { No. of } \\
\text { pods/plant }\end{array}$ & $\begin{array}{l}\text { No. of } \\
\text { pods/ } \\
\text { cluster }\end{array}$ & $\begin{array}{l}\text { No. of } \\
\text { pod } \\
\text { clusters/ } \\
\text { plant }\end{array}$ & $\begin{array}{l}\text { Pod } \\
\text { length } \\
(\mathrm{cm})\end{array}$ & $\begin{array}{l}\text { No. of } \\
\text { seeds/pod }\end{array}$ & $\begin{array}{l}100 \\
\text { seed } \\
\text { weight } \\
(\mathrm{g})\end{array}$ & $\begin{array}{l}\text { Seed } \\
\text { yield } \\
\text { per plant } \\
(\mathrm{g})\end{array}$ \\
\hline I & 9 & 100.50 & 122.72 & 169.33 & 184.85 & 13.28 & 251.00 & 2.67 & 60.39 & 5.30 & 4.83 & 8.58 & 28.13 \\
\hline II & 16 & 102.31 & 127.72 & 175.56 & 193.70 & 15.06 & 242.31 & 2.75 & 55.31 & 5.27 & 4.00 & 7.76 & 30.74 \\
\hline III & 12 & 106.29 & 132.83 & 182.00 & 179.34 & 14.83 & 260.67 & 2.79 & 55.25 & 5.30 & 4.00 & 10.17 & 35.40 \\
\hline IV & 8 & 112.12 & 134.88 & 196.19 & 203.16 & 16.38 & 375.75 & 3.12 & 102.56 & 5.58 & 4.25 & 8.70 & 45.06 \\
\hline
\end{tabular}

Table.5 Desirable genotypes based on cluster performance

\begin{tabular}{|l|c|c|c|c|}
\hline \multicolumn{1}{|c|}{ Characters } & \multicolumn{4}{c|}{ Clusters } \\
\cline { 2 - 5 } & \multicolumn{1}{|c|}{ I } & II & III & IV \\
\hline Days to flower initiation & UPAS- 120 & ICPL-6992 & ICPL-6995 & ICPL- 7373 \\
\hline Days to 50\% flowering & UPAS-120 & ICPL-6994 & ICPL-6997 & ICPL-7373 \\
\hline Days to maturity & UPAS-120 & ICPL-6992 & ICPL-7392 & ICPL-7373 \\
\hline Plant height $(\mathbf{c m})$ & ICPL-6994 & ICPL-7005 & ICPL-ICPL & ICPL-7384 \\
\hline $\begin{array}{l}\text { No. of primary } \\
\text { branches/plant }\end{array}$ & ICPL- 6999 & ICPL-7366 & ICPL-87119 & ICPL-7384 \\
\hline No. of pods/plant & & & & \\
\hline Number of pods/cluster & ICPL-7409 & ICPL-6992 & ICPL-7392 & ICPL- 7430 \\
\hline No. of pod clusters/plant & UPAS-120 & ICPL-7389 & ICPL-87119 & ICPL-7385 \\
\hline Pod length (cm) & UPAS-120 & ICPL-7366 & ICPL-7392 & ICPL- 7405 \\
\hline No. of seeds/pod & ICPL-6996 & ICPL-7003 & ICPL-6997 & ICPL-7373 \\
\hline $\mathbf{1 0 0 ~ s e e d ~ w e i g h t ~}(\mathbf{g})$ & ICPL-7000 & ICPL-7389 & ICPL-87119 & ICPL-7373 \\
\hline Seed yield/plant & UPAS-120 & ICPL-7363 & ICPL-7382 & ICPL-7385 \\
\hline
\end{tabular}


Table.6 List of germplasm accessions

\begin{tabular}{|c|c|c|}
\hline S.No. & Germplasm Accessions & Source of material \\
\hline 1. & ICPL-87119 & IIPR, Kanpur \\
\hline 2. & BDN-2 & IIPR, Kanpur \\
\hline 3. & UPAS-120 & IIPR, Kanpur \\
\hline 4. & ICPL-6992 & CRISAT, Patancheru \\
\hline 5. & ICPL-6994 & ICRISAT, Patancheru \\
\hline 6. & ICPL-6995 & ICRISAT, Patancheru \\
\hline 7. & ICPL-6996 & ICRISAT, Patancheru \\
\hline 8. & ICPL-6997 & ICRISAT, Patancheru \\
\hline 9. & ICPL-6999 & ICRISAT, Patancheru \\
\hline 10. & ICPL-7000 & ICRISAT, Patancheru \\
\hline 11. & ICPL-7001 & ICRISAT, Patancheru \\
\hline 12. & ICPL-7002 & ICRISAT, Patancheru \\
\hline 13. & ICPL-7003 & ICRISAT, Patancheru \\
\hline 14. & ICPL-7004 & ICRISAT, Patancheru \\
\hline 15. & ICPL-7005 & ICRISAT, Patancheru \\
\hline 16. & ICPL-7349 & ICRISAT, Patancheru \\
\hline 17. & ICPL-7358 & ICRISAT, Patancheru \\
\hline 18. & ICPL-7359 & ICRISAT, Patancheru \\
\hline 19. & ICPL-7362 & ICRISAT, Patancheru \\
\hline 20. & ICPL-7363 & ICRISAT, Patancheru \\
\hline 21. & ICPL-7364 & ICRISAT, Patancheru \\
\hline 22. & ICPL-7366 & ICRISAT, Patancheru \\
\hline 23. & ICPL-7367 & ICRISAT, Patancheru \\
\hline 24. & ICPL-7373 & ICRISAT, Patancheru \\
\hline 25. & ICPL-7374 & ICRISAT, Patancheru \\
\hline 26. & ICPL-7376 & ICRISAT, Patancheru \\
\hline 27. & ICPL-7379 & ICRISAT, Patancheru \\
\hline 28. & ICPL-7382 & ICRISAT, Patancheru \\
\hline 29. & ICPL-7384 & ICRISAT, Patancheru \\
\hline 30. & ICPL-7385 & ICRISAT, Patancheru \\
\hline 31. & ICPL-7387 & ICRISAT, Patancheru \\
\hline 32. & ICPL-7388 & ICRISAT, Patancheru \\
\hline 33. & ICPL-7389 & ICRISAT, Patancheru \\
\hline 34. & ICPL-7391 & ICRISAT, Patancheru \\
\hline 35. & ICPL-7392 & ICRISAT, Patancheru \\
\hline 36. & ICPL-7393 & ICRISAT, Patancheru \\
\hline 37. & ICPL-7397 & ICRISAT, Patancheru \\
\hline 38. & ICPL-7398 & ICRISAT, Patancheru \\
\hline 39. & ICPL-7404 & ICRISAT, Patancheru \\
\hline 40. & ICPL-7405 & ICRISAT, Patancheru \\
\hline 41. & ICPL-7406 & ICRISAT, Patancheru \\
\hline 42. & ICPL-7409 & ICRISAT, Patancheru \\
\hline 43. & ICPL-7420 & ICRISAT, Patancheru \\
\hline 44. & ICPL-7429 & ICRISAT, Patancheru \\
\hline 45. & ICPL-7430 & ICRISAT, Patancheru \\
\hline
\end{tabular}


Table.7 The skeleton of analysis of variance for Randomized Complete Block Design (RBD)

\begin{tabular}{|l|l|l|l|l|}
\hline \multicolumn{1}{|c|}{ Source } & \multicolumn{1}{c|}{ D.F. } & \multicolumn{1}{c|}{ SS } & \multicolumn{1}{c|}{ MSS value } \\
\hline Replications & $(\mathrm{r}-1)$ & SSR & MSR & MSR / MSE \\
Genotypes & $(\mathrm{t}-1)$ & SST & MST & MST / MSE \\
Error & $(\mathrm{r}-1)(\mathrm{t}-1)$ & SSE & MSE & \\
\hline Total & $\mathrm{rt}-1 \quad$ & TSS & \\
\hline \multicolumn{5}{|l}{ Where, $\mathrm{r}=$ Number of replications. $\mathrm{t}=$ number of genotypes }
\end{tabular}

Hence, genotypes belonging to this cluster viz., ICPL-7373, ICPL-7384, ICPL-7430 and ICPL-7405 may be utilized as parent in future breeding programmes with the genotypes belonging to cluster I i.e., UPAS-120, ICPL6994, ICPL-6996 and ICPL-7409 as the maximum inter cluster distance was noted between the cluster I and Cluster IV.

The experimental findings of cluster analysis are in general agreement with the findings of Sarma and Roy (1994), Nandan et al., (1996), Basawarajaiah et al., (2000), Gohil (2006), Mahamad et al., (2006) (Table 5-7).

Summary and conclusions of the study are as follows:

Association studies revealed that seed yield per plant showed the highest significant positive correlation with number of pods per plant followed by number of pod clusters per plant, number of primary branches per plant and pod length. Moreover, number of pods per plant was found to be correlated positively with days to maturity, number of primary branches and number of pod clusters per plant. Days to flower initiation had positive correlation with days to $50 \%$ flowering and days to maturity. Whereas, days to $50 \%$ flowering showed positive correlation with days to maturity. Hence, direct selection for number of pods per plant, number of pod clusters per plant and pod length may be advantageous for selecting the high yielding genotypes in pigeonpea from the available germplasm accessions. Cluster analysis result showed existence of considerable diversity in pigeonpea germplasm accessions. The highest intra cluster distance was observed for the cluster IV. Hence, genotypes belonging to this cluster viz., ICPL-7373, ICPL-7384, ICPL7430 and ICPL-7405 may be utilized as parent in future breeding programmes with the genotypes belonging to cluster I i.e., UPAS-120, ICPL-6994, ICPL-6996 and ICPL-7409 as the maximum inter cluster distance was noted between the cluster I and Cluster IV. This suggested that the hybridization programme involving parents from these clusters is expected to give higher frequency of better segregates or desirable combination for development of useful genetic stocks or varieties.

\section{References}

Basavarajaiah, D., Gowda, M.B., Lohithaswa, H.C. and Kulkarni, R.S. 2000. Assessment of pigeonpea germplasm and isolation of elite genotypes for Karnataka. Crop Research Hisar, 20(3): 444-448.

Chandirakala, R. and Subbaraman, N. 2010. Character association and path analysis for yield attributes in full sib progenies in Pigeonpea [Cajanus cajan (L.) Millsp.]. Electronic Journal of Plant Breeding, 1(4): 824-827.

Chochran, W.G. and Cox, G.M. 1957. Experimental Designs. Asia Publication House, Bombay.

Fattepurkar, S.C., Munjal, S.V. and Patil, S.R., 2004. Evaluation of proximate 
composition and limiting amino acids content in grains of some pigeonpea genotypes. Indian J. Pulses Res., 17(2): 167-169.

Gohil, R.H. 2006. Genetic divergence in pigeonpea [Cajanus cajan $(L)$. Millsp.]. Research on Crops, 7(3): 748-750.

Kalaimagal, T., Balu, P.A. and Sumathi, P. 2008. Genetic studies in segregating populations of pigeonpea [Cajanus cajan (L.) Millsp.]. Crop Improvement, 35(1): 31-34.

Linge, S.S., Kalpande, H.V., Sawargaonkar, S.L., Hudge, B.V. and Thanki, H.P. 2010. Study of genetic variability and correlation in interspecific derivatives of Pigeonpea [Cajanus cajan (L.) Millsp.]. Electronic Journal of Plant Breeding, 1(4): 929-935.

Mahamad, F., Gowda, M. B. and Girish, G. 2006. Genetic variability and association studies in vegetable pigeonpea. Environment and Ecology, 24S (Special 4): 1124-1129.

Mittal, V.P., Brar, K.S. and Singh, P. 2006. Identification of component traits contributing to seed yield in pigeonpea (Cajanus cajan (L.) Millsp]. Journal of Arid Legumes, 3(2): 66-67.

Nene, Y.L., 1987. Overview of pulses research at ICRISAT. Adoption of Chickpea and Pigeonpea to abiotic stresses, International Crop Research Institute for Semi-Arid Tropics (ICRISAT), Patancheru, India. pp. 7-12.

Sarma, R.N. and Roy, A. 1994. Genetic divergence in early maturing pigeonpea. Indian J. Genet., 54(2): 184-187.

Singh, F., Katiyar, P.K., Singh, I.P., Majumder, N.D. and Singh, B.B. 2008. Genetic divergence and interrelationships among yield parameters in short duration pigeonpea. Journal of Food Legumes, 21(1): 31-34.

Sodavadiya, P.R., Pithia, M.S., Savaliya, J.J., Pansuriya, A.G. and Korat, V.P. 2009. Studies on characters association and path analysis for seed yield and its components in pigeonpea [Cajanus cajan (L.) Millsp.]. Legume Research, 32(3): 203-205.

\section{How to cite this article:}

Yogesh Kumar Nag and Sharma, R.N. 2019. To Formulate the Suitable Selection Criteria Based on Cluster and Association Analysis for Yield Maximization. Int.J.Curr.Microbiol.App.Sci. 8(01): 1594-1602. doi: https://doi.org/10.20546/ijcmas.2019.801.168 